\title{
Perancangan Washtafel Sebagai Media Pencegaha Penyebaran Covid-19 Di Desa Selat, Susut, Bangli
}

\author{
I Wayan Balika Ika, I Gede Ari Permana Putra
}

Program Studi Desain Interior, Fakultas Seni Rupa dan Desain

Institut Seni Indonesia Denpasar

Pada masa pandemi saat ini yang menjelang diberlakukan new normal, masih banyak masyarakat yang kurang paham pentingnya pencegahan penularan Covid-19. Salah satu cara agar masyarakat paham mengenai penanganan Covid-19 dan penerapan new normal maka penulis merancang media cuci tangan berupa washtafel yang dapat digunakan tanpa disentuh tangan. Perancangan tersebut dilengkapi poster untuk memberikan informasi yang mudah dipahami mengenai penggunaan washtafel serta tata cara mencuci tangan yang baik dan benar. Pelaksanaan program kerja KKN mengalami kendala karena adanya keterbatasan ruang gerak dalam melaksanakan kegiatan survei. Namun, hal tersebut mampu diatasi karena sikap yang kooperatif dari berbagai pihak demi kelancaran pelaksanaan kegiatan KKN di Desa Selat.

Kata kunci: perancangan, wasftafel, poster, Covid-19, KKN 


\section{PENDAHULUAN}

Kuliah Kerja Nyata (KKN) adalah sebuah bentuk kegiatan pengabdian dari mahasiswa kepada masyarakat dengan mengacu pada pendekatan lintas keilmuan pada waktu dan daerah tertentu. Pelaksanaan KKN biasanya berlangsung antara satu sampai dengan dua bulan dan berlangsung di daerah setingkat desa. Dalam pelaksanaanya diharapkan masyarakat maupun mahasiswa mendapat keuntungan berupa ilmu atau hal lainnya yang dapat digunakan untuk menjalani kehidupan. Pada masa pandemi saat ini, Institut Seni Indonesia Denpasar mengarahkan mahasiswa untuk melakukan kegiatan KKN di daerah tempat tinggal masing-masing untuk menghindari penyebaran virus Covid-19 dan tetap mematuhi protokol kesehatan.

Desa Selat, Kecamatan Susut, Bangli merupakan tempat yang penulis pilih sebagai tempat melaksanakan KKN. Desa Selat memiliki tiga banjar adat yaitu Banjar Adat Selat Peken, Banjar Adat Selat Tengah, dan Banjar Adat Selat Kaja Kauh. Penduduk di wilayah Banjar Adat Selat Peken mayoritas penduduknya bekerja sebagai petani, pedagang maupun buruh serabutan. Selain itu, adapula yang berprofesi sebagai PNS serta merantau keluar kota sebagai pekerja maupun pelajar. Masyarakat yang bekerja sebagai petani, pedagang, buruh, dan anakanak sebagian besar belum mematuhi protokol kesehatan. Mereka belum menerapkan penggunaan masker pada saat bekerja ke sawah, pergi ke pasar, tidak mencuci tangan ketika datang dari tempat umum, dan tidak membawa hand sanitizer. Hal tersebut menyebabkan pemerintah daerah kesulitan untuk memberi himbauan kepada masyarakatnya untuk mengikuti protokol kesehatan.

Pada masa pandemi saat ini yang menjelang diberlakukan new normal, masih banyak masyarakat yang kurang paham pentingnya pencegahan penularan Covid-19. Pencegahan tersebut dapat dilakukan dengan cara yang sangat mudah, yaitu menggunakan masker dan menjaga kebersihan diri dengan mencuci tangan yang baik dan benar. Kurangnya kesadaran masyarakat menyebabkan penularan Covid-19 menjadi sangat cepat dan luas. Aparat desa telah berupaya untuk memberikan informasi tentang penanganan Covid-19, namun tidak membuat masyarakat paham dengan dampak pandemi tersebut.
Salah satu cara agar masyarakat paham mengenai penanganan Covid-19 dan penerapan new normal maka penulis merancang media cuci tangan berupa washtafel yang dapat digunakan tanpa disentuh tangan. Dalam perancangan ini, penulis bekerjasama dengan mahasiswa program studi desain komunikasi visual untuk memaksimalkan rancangan dengan memberi informasi yang mudah dipahami mengenai penggunaan washtafel serta tata cara mencuci tangan yang baik dan benar melalui media poster. Perancangan washtafel dan poster cuci tangan ini diharapkan dapat menjadi salah satu upaya pendukung untuk pencegahan penularan Covid-19, sekaligus memberi fasilitas yang memadai untuk membantu Desa Selat selama pandemi tersebut berlangsung.

Berdasarkan uraian di atas, maka permasalahan yang dapat dirumuskan dalam artikel hasil kegiatan KKN adalah 1) Apa saja program kerja KKN pada masa pandemi Covid-19 di Desa Selat, Susut, Bangli? 2) Apa faktor-faktor yang mempengaruhi pelaksanaan program kerja KKN pada masa pandemi Covid-19 di Desa Selat, Susut, Bangli?

\section{PEMBAHASAN}

\section{Program Kerja KKN di Desa Selat}

Program kerja KKN yang dilakukan di Desa Selat pada masa pandemi Covid-19 adalah merancang dan menerapkan media washtafel untuk membantu desa dalam rangka meningkatkan kesadaran masyarakat setempat. Program kerja KKN diawali pertemuan mahasiswa pelaksana kegiatan KKN dengan Kepala Desa Selat pada Senin, 3 Agustus 2020 di Kantor Desa Selat.

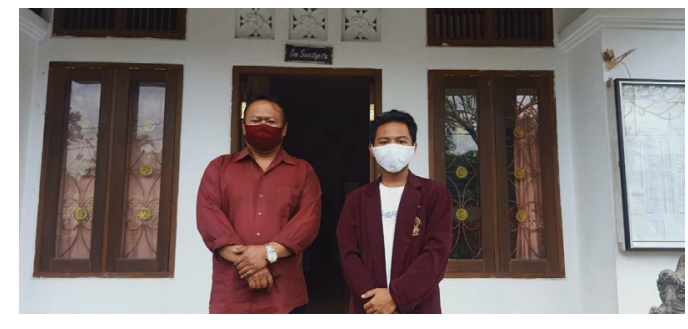

Gambar 1. Pertemuan awal mahasiswa dengan Kepala Desa Selat (Sumber: dokumen pribadi)

Kegiatan pertemuan tersebut membahas perkenalan diri mahasiswa, tujuan pelaksanaan $\mathrm{KKN}$, potensi dan keadaan desa, serta beberapa agenda lainnya. Melalui hasil pertemuan dengan Kepala Desa Selat, 
dapat diperoleh gambaran umum tentang keadaan desa selama pandemi Covid-19, sehingga program kerja dapat dirancang sesuai dengan kebutuhan desa setempat. Adapun ide rancangan sebagai bentuk pemecahan masalah dalam penanganan pandemi Covid-19 di Desa Selat adalah merancang washtafel atau tempat cuci tangan. Ide yang telah dituangkan dalam bentuk tulisan dan sketsa, selanjutnya diajukan kepada kepala desa pada Selasa, 4 Agustus 2020.

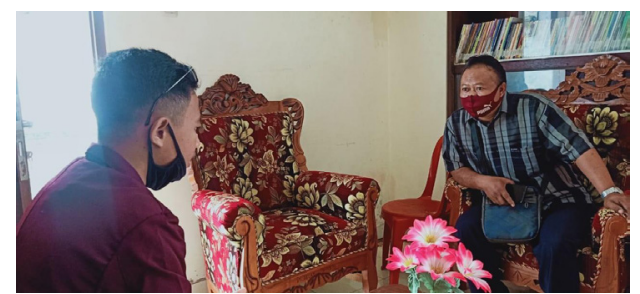

Gambar 2. Pengajuan ide rancangan kepada Kepala Desa Selat (Sumber: dokumen pribadi)

Kepala desa menerima ide untuk merancang washtafel dengan beberapa perbaikan agar menyesuikan dengan situasi dan kondisi desa serta masyarakat setempat. Saran perbaikan tersebut dicatat untuk dijadikan pedoman penyempurnaan rancangan media washtafel. Pada hari yang sama, kegiatan berikutnya adalah survei lapangan untuk meninjau lokasi yang berpotensi menjadi tempat penerapan rancangan media washtafel.

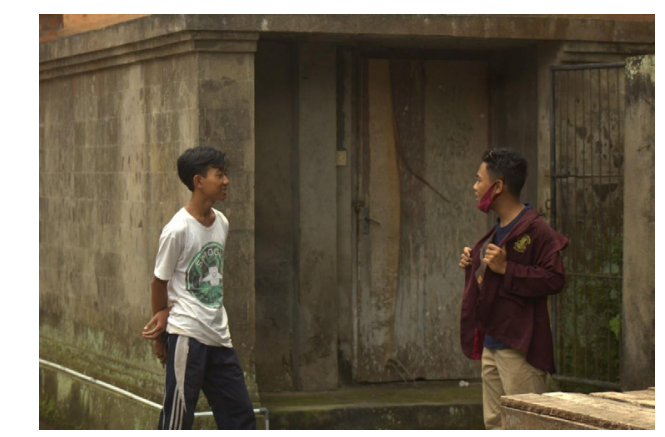

Gambar 3. Survei lapangan penerapan media washtafel (Sumber: dokumen pribadi)

Survei lapangan tersebut menghasilkan beberapa pilihan lokasi yang akan dipelajari lebih lanjut agar sesuai dengan rancangan media washtafel yang telah mendapatkan saran perbaikan dari Kepala Desa Selat. Proses penentuan lokasi penerapan memerlukan waktu 8 hari karena diselingi oleh beberapa kegiatan $\mathrm{KKN}$ lainnya, seperti penyemprotan disinfektan dan mengajarkan pembuatan ketrampilan kepada anak-anak di sekitar Desa Selat. Adapun lokasi yang ditetapkan sebagai tempat penerapan media washtafel adalah di pasar Banjar Selat Peken, Desa Selat. Pada Rabu, 12 Agustus 2020 dilaksanakan survei lokasi di pasar Banjar Selat Peken untuk memaksimal rancangan media washtafel agar sesuai dengan arahan perbaikan dari kepala desa.

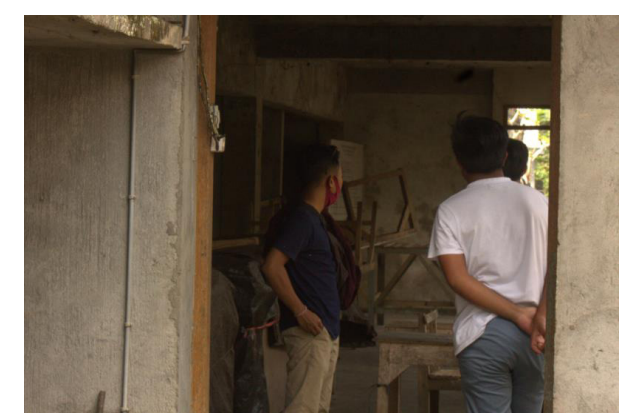

Gambar 4. Survei lokasi penerapan media washtafel di Banjar Selat Peken

(Sumber: dokumen pribadi)

Informasi yang diperoleh melalui survei lokasi di pasar Banjar Selat Peken dicatat dan dituangkan ke dalam perbaikan sketsa media washtafel pada 1718 Agustus 2020. Sketsa harus memenuhi beberapa syarat antara lain mudah diterapkan dan digunakan oleh masyarakat setempat serta meminimalisir sentuhan tangan pada media washtafel untuk mencegah penyebaran Covid-19.

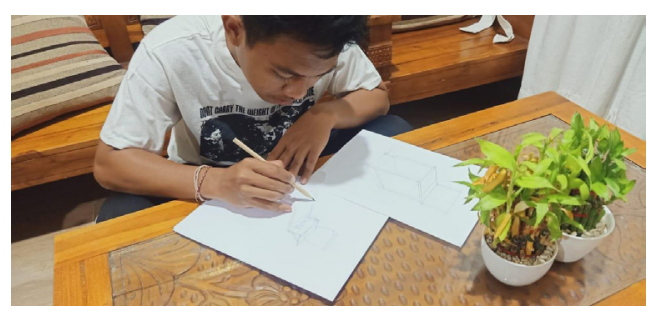

Gambar 5. Perbaikan sketsa media washtafel (Sumber: dokumen pribadi)

Sketsa media washtafel juga dilengkapi dengan media komunikasi visual pada bagian atas keran air berupa poster informasi penggunaan washtafel serta tata cara mencuci tangan yang baik dan benar. Media tersebut dirancang bersama dengan mahasiswa program studi desain komunikasi visual pada 19-20 Agustus 2020. 


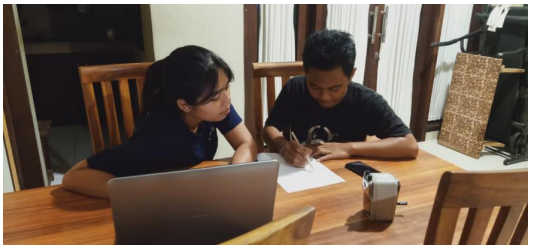

Gambar 6. Perancangan media komunikasi visual bersama mahasiswa DKV

(Sumber: dokumen pribadi)

Rancangan media washtafel dan poster dipresentasikan dihadapan sekretasi desa sebagai perwakilan Kepala Desa Selat pada Senin, 24 Agustus 2020. Rancangan kedua media tersebut mendapatkan saran dan perbaikan kembali agar mampu diterapkan secara maksimal untuk membantu masyarakat dan pemerintah desa dalam mencegah penyebaran Covid-19.

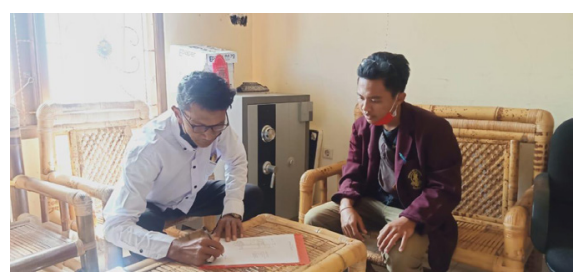

Gambar 7. Konsultasi media washtafel dan poster bersama Sekretaris Desa Selat

(Sumber: dokumen pribadi)

Sekretaris Desa Selat memberikan perbaikan pada beberapa bagian yang tidak terlalu siginifikan memengaruhi bentuk media washtafel dan poster. Dengan demikian, perwujudan media washtafel dan poster dapat dilaksanakan pada keesokan harinya, yaitu pada 25-28 Agustus 2020.

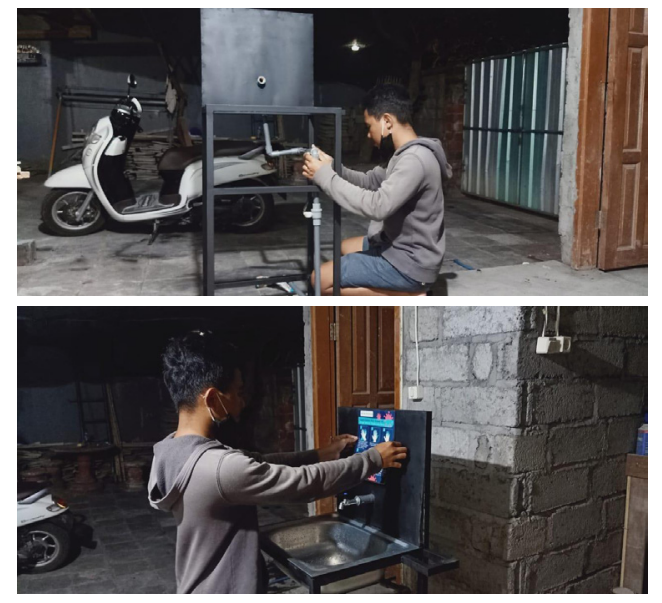

Gambar 8. Perwujudan media washtafel dan poster (Sumber: dokumen pribadi)
Perwujudan media washtafel telah memenuhi syarat yang mudah digunakan oleh masyarakat setempat serta meminimalisir sentuhan tangan dengan menerapkan pedal penginjak untuk membuka keran air. Air akan keluar melalui keran apabila pengguna washtafel menginjak pedal dengan menggunakan salah satu kaki yang terkuat agar debit air dapat keluar dengan normal. Media washtafel dan poster yang telah selesai diwujudkan, kemudian diterapkan di depan toilet pasar Banjar Selat Peken pada 29 Agustus 2020.

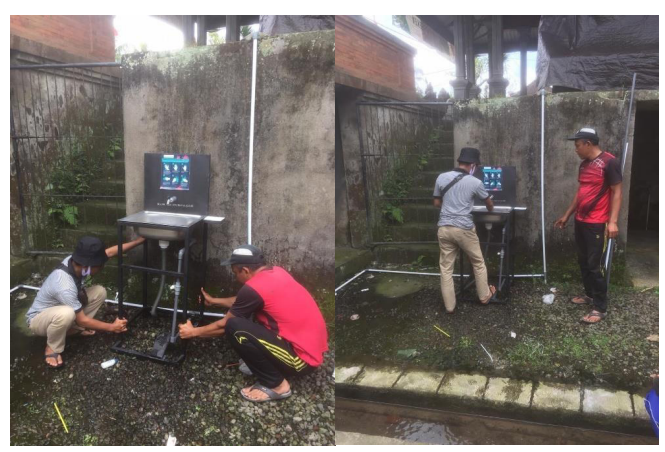

Gambar 9. Pemasangan media washtafel dan poster di depan toilet pasar Banjar Selat Peken

(Sumber: dokumen pribadi)

Pemasangan media washtafel dan poster di lokasi tersebut disaksikan langsung oleh kelihan Banjar Selat Peken. Selain itu, mahasisa pelaksana kegiatan KKN juga langsung mendemonstrasikan tata cara penggunaan washtafel serta langkah-langkah mencuci tangan yang baik dan benar agar mampu ditiru oleh masyarakat setempat. Perancangan media washtafel dan poster ini diharapkan mampu menjadi langkah awal dalam membangkitkan kesadaran masyarakat Desa Selat dan membantu pemerintah Desa Selat mencegah penyebaran Covid-19 agar kehidupan bermasyarakat dapat kembali berjalan dengan normal.

\section{Faktor yang Memengaruhi Program Kerja KKN di Desa Selat}

Pelaksanaan program kerja KKN di Desa Selat mengalami beberapa kendala yang disebabkan oleh keterbatasan ruang gerak dalam melakukan kegiatan survei. Dampak yang ditimbulkan dari kendala tersebut adalah memerlukan waktu yang cukup lama untuk melakukan survei karena harus menunggu izin dan memenuhi beberapa syarat dari pengelola banjar atau tempat-tempat lainnya agar sesuai dengan protokol kesehatan. 
Adapun faktor yang mendukung atau membantu mahasiswa dalam melaksanakan kegiatan KKN di Desa Selat adalah respon yang kooperatif dari pemerintah desa, banjar, dan pengelola tempattempar survei lainnya. Pihak-pihak tersebut sangat antusisas menyambut pelaksanaan kegiatan KKN ISI Denpasar karena bantuan mahasiswa sangat dibutuhkan untuk mencari solusi dari kendala pencegahan penyebaran Covid-19 di Desa Selat, Susut, Bangli.

\section{SIMPULAN}

Program kerja KKN di Desa Selat, Susut, Bangli adalah perancangan media washtafel beserta poster tata cara penggunaan dan mencuci tangan yang baik dan benar. Hal tersebut sesuai dengan kendala yang dialami oleh Desa Selat, yaitu kurangnya kesadaran masyarakat setempat dalam rangka mencegah penyebaran Covid-19. Faktor yang menghambat mahasiswa pelaksana kegiatan KKN adalah keterbatasan ruang gerak dalam melaksanakan kegiatan survei. Selain itu, adapula faktor yang mendukung kelancaran kegiatan $\mathrm{KKN}$ adalah sikap yang kooperatif dari berbagai pihak, seperti pemerintah desa, banjar, dan pengelola tempattempat survei lainnya di Desa Selat.

\section{DAFTAR RUJUKAN}

Kementerian Kesehatan Republik Indonesia. COVID-19 dalam Angka - Kondisi 29 Agustus 2019. Jakarta: Kemenkes RI dan Germas, 2020. 31 Agustus 2020. https://www.kemkes. go.id/resources/download/infoterkini/covid\%20 dalam\%20angka/covid-19-dalam-angka-29agustus-2020.pdf

Kementerian Kesehatan Republik Indonesia. Kampanye Nasional Disiplin Pakai Masker. Jakarta: Depkes RI dan Kemenkes RI, 2020. 31 Agustus 2020. https://www.kemkes.go.id/article/ view/20083000003/kampanye-nasional-disiplinpakai-masker.html

Mudana, I Nyoman. Penyemprotan Disinfektan Pencegah Penyebaran Virus COVID-19. Bangli: Website Desa Selat, 2020. 31 Agustus 2020. https://selat-susut.desa.id/opensid/index. php/artikel/2020/4/1/penyemprotan-disinfektanpencegah-penyebaran-virus-covid-19
Mudana, I Nyoman. Posko Terpadu Penanggulangan COVID-19. Bangli: Website Desa Selat, 2020. 31 Agustus 2020. https://selat-susut.desa.id/ opensid/index.php/artikel/2020/4/7/posko -terpadu-penanggulangan-covid-19

Mudana, I Nyoman. Profil Wilayah Desa Selat, Susut, Bangli. Bangli: Website Desa Selat, 2016. 31 Agustus 2020. https://selat-susut.desa.id/opensid/ index.php/artikel/2016/8/26/wilayah-desa 